\title{
Anomalous Geomagnetic Field Modeling for Crustal Structure of a Graben in West Siberia
}

\author{
Nikolay Pavlovich Kostrov, Kirill Svjatoslavich Ivanov \\ Institute of Geology and Geochemistry, Urals Branch of Russian Academy of Sciences, Yekaterinburg, Russia \\ Email: kostrov65@yandex.ru
}

How to cite this paper: Kostrov, N.P. and Ivanov, K.S. (2018) Anomalous Geomagnetic Field Modeling for Crustal Structure of a Graben in West Siberia. Open Journal of Geology, 8, 232-246. https://doi.org/10.4236/ojg.2018.83015

Received: February 21, 2018

Accepted: March 23, 2018

Published: March 26, 2018

Copyright ( 2018 by authors and Scientific Research Publishing Inc. This work is licensed under the Creative Commons Attribution International License (CC BY 4.0).

http://creativecommons.org/licenses/by/4.0/

(c) (i) Open Access

\begin{abstract}
An intensive magnetic anomaly within the limits of West Siberia Danilov graben-rift indicates magnetic rocks while numerous wells encountered only weakly magnetized Triassic basalts and liparites in the basement covered by thick loose Jurassic and younger sediments. The wells penetrated only the first tens meters of the basement and could not tell us about the liparites structure at depth where supposedly they may form a big single body and magnetic rocks may be situated deeper. Geological ideas on a graben-rift structure may be proved (or rejected) by a computer modeling of its magnetic properties. For the anomalous geomagnetic field interpretation, a method of volume integral equations taking into account demagnetization effect was employed. To fit a model a trial-and-error procedure was utilized. The results show that 1 ) at the depth some rocks are magnetized in opposite direction to the present field; 2) highly magnetized rocks (magnetic susceptibility 0.06 - 0.1SI) coming up continuously from the bottom of the model and situated under the graben; 3 ) the studied structure is not a graben but the rift because the continental light crust is absent.
\end{abstract}

\section{Keywords}

Graben-Rift, Geomagnetic Anomaly, Modeling, Integral Equation, Interpretation

\section{Introduction}

The pioneer researchers of West Siberia empirically found that the main oil deposits of the region are related to the system of Triassic rifts ([1] [2] and other) and located predominately in such places in the basement, where Precambrian complexes had been developed. The conducted analysis has shown that two groups of reasons cause this: 1) Rifts destroy continental crust and are regional 
penetrable zones draining the upper mantle and it is in these zones that deep fluids easy penetrate in the sedimentary cover; 2) Deformations and structures of the sedimentary cover are defined by the basement. Thickness of the basement of West Siberia plate in average 14 times exceeds thickness of the cover. Taking into account average strength of basement rocks $(153 \pm 10 \mathrm{MPa})$ and other factors one may conclude that its strength of two orders of magnitude is greater than the strength of the sedimentary cover. Sialic blocks (considered earlier as Precambrian) are composed of middle-low crust rocks, predominantly granitoids and metamorphic schists, with density deficiency $0.07-0.1 \mathrm{~g} / \mathrm{cm}^{3}$ (relatively to the mean earth crust density $2.67 \mathrm{~g} / \mathrm{cm}^{3}$ ). These blocks come to the level of the upper crust in time of Triassic rifting and continue isostatically "floating" after Triassic time. As a result, antiforms in sedimentary cover were created above them. Later the antiforms were filled with oil.

A modeling area is the central part of Danilov graben-rift that situated in Khanty-Mansi autonomous district (KhMAD) of the central part of the West Siberia oil and gas basin. KhMAD is the main oil region of the country-about half of Russian oil is produced here. The modeling area may be considered as a standard for the entire West Siberia taking into consideration that Danilov and North-Danilov oilfields are here and there are representative geophysical and wellsite data. Besides, vast majority of wells encountered only the uppermost parts of the basement not only in the modeling area but also throughout West Siberia that make it difficult to study graben-rift structures and as well as to detect and classify faults. Therefore, it is of importance to clarify the structure of the standard area utilizing potential field information and geophysical approach in computer modeling. It should be said that such modeling was done for the first time in the study area as scientists worldwide constantly address the potential field interpretation for graben and rift studies [3]-[13].

Magnetic anomalies allow us to trace earth crust faults, borders of blocks and structures [14] [15]. In particular, the relatively magnetic serpentinites are able to make chain anomalies along graben borders. On the other hand, the fact that an intense magnetic anomaly is observed in the limits of Danilov graben-rift of West Siberia but numerous wells encountered only weakly magnetized Triassic graben basalts and liparites, leads us to conclusion that magnetic rocks are situated at great depth. In addition, we suppose that the liparites joint together in a single body. In fact, the wells penetrated only the first tens meters of the basement that covered everywhere by loose sediments of Jurassic and younger age with thickness of $1.5-2.5 \mathrm{~km}$.

Besides, geomagnetic data themselves do not give a guaranty of single-valued interpretation because of potential character of the field. Therefore, fitting of magnetic characteristic having in mind reasonable geological constraints, allows not only testing geological hypotheses but also refining existing structural maps. Thus, validity of geological conceptions on graben-rift structure can be proved or denied with the help of computer modeling. 
The purpose of the present study is to build magnetic model of the central part of Triassic Danilov graben situated within Khanty-Mansi autonomous district (KhMAD) of central part of the West Siberia oil and gas basin.

\section{Geological Background}

West Siberia basement has been studied for more than fifty years [16] [17] [18]-[24]. The efforts have resulted in detecting many grabens originated in rift formation process that supposedly are responsible for forming oil and gas deposits [25] [26]. It is generally recognized that all West Siberia was subjected to rifting that leaves traces in the form of branching graben system covered by Mesozoic and Cenozoic sediments [27]. In the central part of West Siberia, in the limits of junction zone of the eastern slope of the Urals and Tyumen region of KhMAD, two Triassic graben-rifts were singled out [28] [29]: northern Sosva (at the east slope of the Urals) and Danilov (in the western part of KhMAD). Danilov graben-rift geology (Figure 1) can be considered as a standard for such structures.

\section{Method}

3D magnetic model was built with a trial-and-error procedure when repeatedly solving a direct problem. The method was realized in software program complex "3D Interpretation of potential fields" [30] [31]. Our fitting methodology takes into account the a priori geological information [32] [33] [34] as well as ideas on graben-rift formation processes. Thus, in the given method an interpreter specifies initial conditions that include geometry of the basement, magnetizing field, magnetic susceptibility and remanent magnetization distributions and obtains at the end total force anomalous magnetic field (AMF), which is compared with observed AMF. Then model is changed and procedure is repeated unless satisfactory fitting is obtained. In doing so in the fitting, many times the following equation for magnetic field $\boldsymbol{H}(\boldsymbol{r})$ is solved [35]:

$$
\boldsymbol{H}(\boldsymbol{r})=\boldsymbol{H}_{0}(\boldsymbol{r})-\frac{1}{4 \pi} \nabla \int_{V_{2}}\left(\boldsymbol{\kappa}\left(\boldsymbol{r}^{\prime}\right) \boldsymbol{H}\left(\boldsymbol{r}^{\prime}\right)+\boldsymbol{R}\left(\boldsymbol{r}^{\prime}\right)\right) \frac{r-\boldsymbol{r}^{\prime}}{\left|r-r^{\prime}\right|^{3}} \mathrm{~d} V_{2},
$$

where $\left|r-r^{\prime}\right|=\sqrt{\left(x-x^{\prime}\right)^{2}+\left(y-y^{\prime}\right)^{2}+\left(z-z^{\prime}\right)^{2}}, \quad r^{\prime}$-the radius-vector of a source point $P^{\prime}\left(x^{\prime}, y^{\prime}, z^{\prime}\right), \boldsymbol{r}$-the radius vector of an observation point $P(x, y, z)$, in which we calculate the field, $\kappa\left(r^{\prime}\right)$-magnetic susceptibility. An observation point may be inside or outside of a source body. The equation can be obtained from anomalous field definition [36] or from Maxwell equations by standard procedure involving Green's theorem application [37] [38] [39] [40]. The equation is solved by a numerical method based on [41] [42].

The magnetic model was based on our previously constructed density model [43]. The density model of the Danilov graben has shown that rocks with a significantly excess density of $0.3 \mathrm{~g} / \mathrm{cm}^{3}$ and higher, which probably represent the Triassic mantle diapir, should be located under the axial part of the graben. 


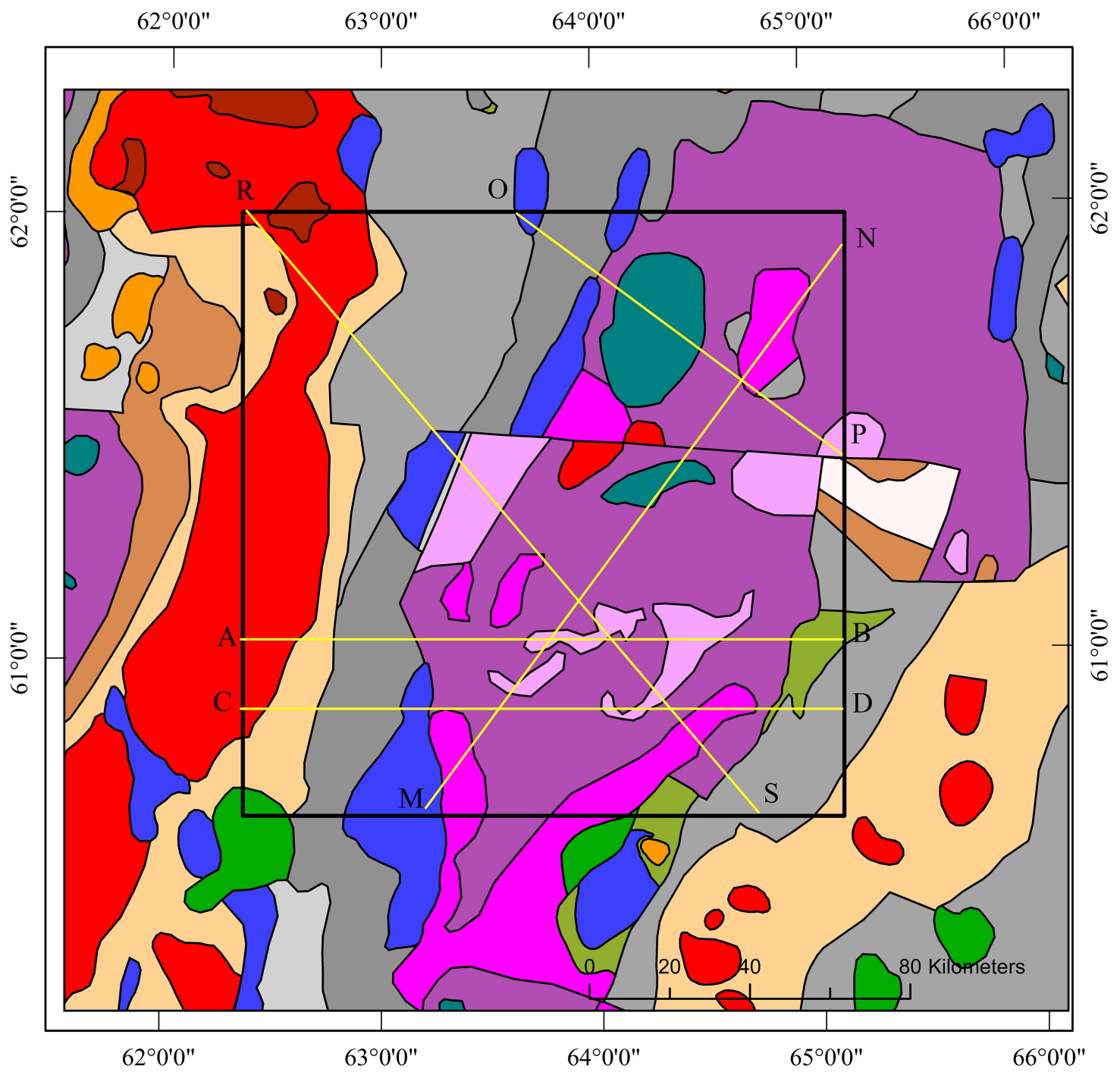

\section{Legend}

$\square$ Triassic liparites

Triassic basalt-terrigeneous

formation

Effusive rocks with tuffs

Low Triassic basalts

Gabbro-dolerites

Carboniferous Tournaisian -

Visean terrigeneous-

carbonate sediments

Devonian volcanogenic-

sedimentary formation

\section{Profiles}

Middle-Late Devonian

limestones

Low Paleozoic porphyrites,

diabases and jasper

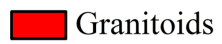

Sialic gneiss and schists

$\square$ Quartz diorites

Carboniferous terrigenousschist formation

Late Devonian-Early

Carboniferous effusives

$\square$ Plagiogranites, granodiorites

Gabbro

$\square$ Ultrabasites

model-area

Figure 1. Geological map of Danilov graben-rift of West Siberia. The black rectangle shows a modeling area. Yellow straight lines inside the model area are vertical cross-section profiles. 
Rhyolites, forming small irregular bodies on the geological map of the basement, are combined into the common lopolith-like subvolcanic body at depths. The graben is flattened toward the north, which explains the previously unclear presence of Carboniferous shales among the Triassic rocks in the northern part of the structure. In the course of modeling we achieved good correspondence of magnetic and density geometry. The correctness of the gravitation model was checked by the magnetic model of the graben-rift. Actually, we have a single graben-rift model, in which we fitted different parameters (density, magnetic susceptibility, natural remanent magnetization) and geometry of the bodies.

\section{Technical Characteristic of the Model}

In modeling, we used a rectangular system of coordinates with the vertical axis pointed upwards, the abscissa directed eastward and the ordinate directed to the north. Gauss-Krüger projection for the 11 zone was used to transfer geological formation contours to the "Complex...". The final model contains 222,301 elementary cells located in 22 horizontal layers. In horizontal plane, an elementary cell has a dimension of $1.5 \times 1.5 \mathrm{~km}$. A layer contains 10,100 elementary cells. Each elementary cell is assigned magnetic susceptibility and remanent magnetization. Basement relief begins with a depth of $1.25 \mathrm{~km}$ and continues to a depth of $2.5 \mathrm{~km}$. In this range, a layer thickness of $0.25 \mathrm{~km}$ was used. Deeper, from a depth from 2.5 to $12.5 \mathrm{~km}$, we define thickness of a layer equal to $1 \mathrm{~km}$. The grids of the basement and observed AMF coincide and have a dimension of $74 \times$ 76 nodes. The source AMF is presented for epoch of 1965 (Figure 2, the upper part), which is determined calculation of the magnetizing field in IGRF model [44]. The magnetizing field was calculated at each node of the observed AMF grid and considered constant up to half distance to a next node. The data on magnetic susceptibility were taken typical for the rocks of the area.

\section{Accuracy of Fitting}

An accuracy is characterized by residual field (Figure 2, bottom part) obtained as difference between observed and model AMF. As one can see from the bottom part of Figure 2, the residual field isolines have mosaic structure with fine details in a range of $\pm 30 \mathrm{nT}$ that is about $5 \%$ of the range of the observed AMF (changing from -242 to $1053 \mathrm{nT}$ ) excluding boundaries of the model area.

\section{Results and Discussion}

Our initial supposition that AMF in the area is due to only induced magnetization failed because we cannot model satisfactorily some local negative anomalies above almost nonmagnetic bodies. Another assumption that AMP above the study area contains significant regional component does not confirm. Any filtering of the observed AMF with a purpose to separate regional and local components leads to wide negative anomalies in the local field (taking more than $90 \%$ of the area) that requires remanent magnetization opposite to present 


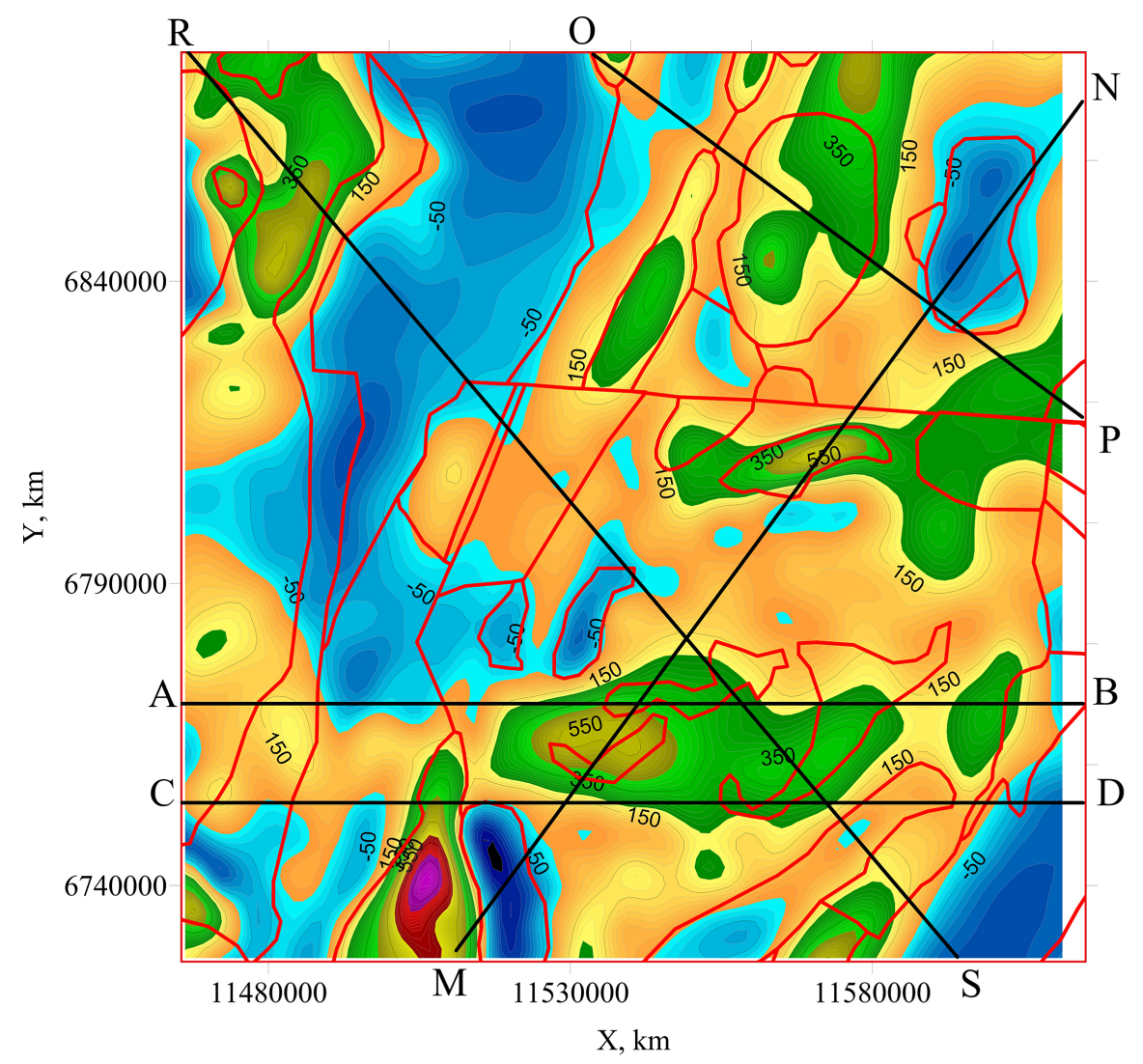

$\mathrm{F}, \mathrm{nT}$

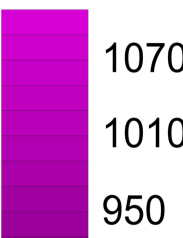

950

890

830

770

710

650

590

530

470

410

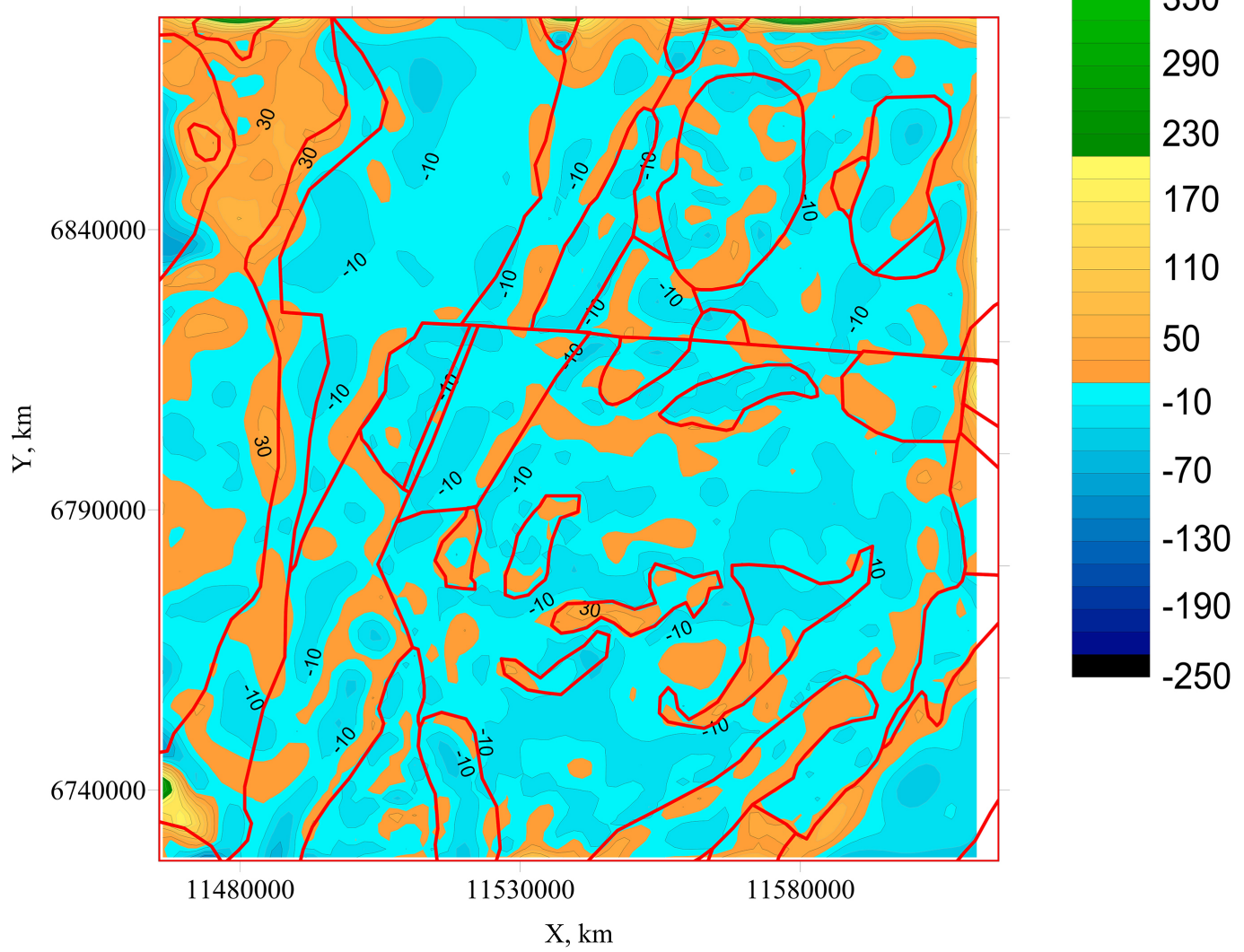

350

290

230

170

110

50

$-10$

$-70$

$-130$

190

$-250$

Figure 2. Magnetic field of the model: observed AMF (the upper part) and residual AMF (the bottom part). Contours of geological formations (Figure 1) are shown in red lines. The cross-section profiles are shown as black straight lines. 
geomagnetic field for all bodies. In the long run, we decide to fit source observed AMF and compensate negative anomalies after taking into account induced magnetization.

As one can see on Figure 3, blocks with opposite to the present geomagnetic field magnetization were inserted at depths from 8.5 to $12.5 \mathrm{~km}$. Other model cells have all components of remanent magnetization equal to zero. We assign values only to z-component of remanent magnetization. Reverse magnetization rocks can be explained by tectonic movement, metasomatosis, or inversion of the main geomagnetic field when rock to form. An analysis of the initial fitting reveals big variety of magnetic susceptibility values that can be grouped in several classes in the ranges of $0-0.00072,0.005-0.007,0.02-0.04$, and $0.07-0.1$ SI units. In some cases, it was useful to get average value for a class and alter body geometry that rather improve quality of the fit. The result is shown on Figure 4, where magnetic susceptibility structure. On the Figure 4 magnetic susceptibility in SI units are shown in every horizontal layer of the model where magnetic susceptibility is not equal to zero. The magnetic susceptibility scale is shown to the right. Subscriptions under each graph is a layer range in vertical direction (z-coordinates) beginning from a depth of $1.25 \mathrm{~km}$ to the bottom of the model $(12.5 \mathrm{~km})$. In the central part of the area, one can trace liparite magnetic susceptibility change with a depth (shown in light blue colors) as well as magnetic

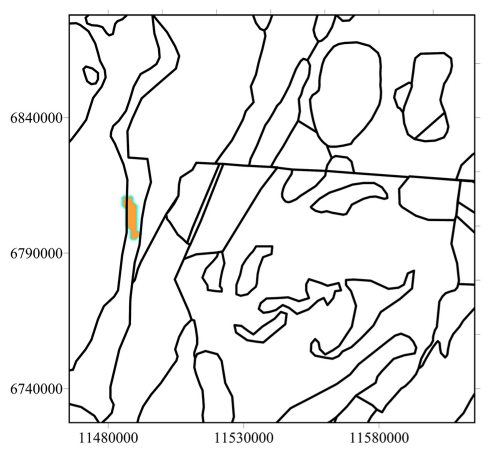

Layer from -8.5 to $-7.5 \mathrm{~km}$

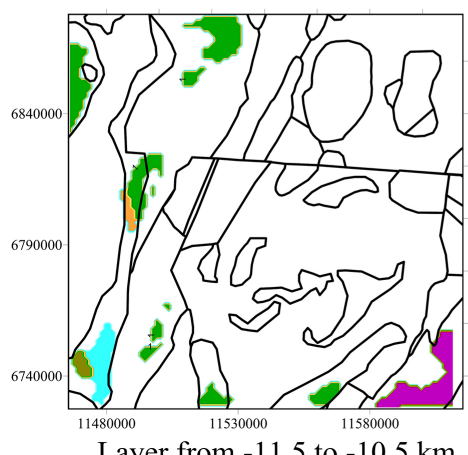

Layer from -11.5 to $-10.5 \mathrm{~km}$
$\mathrm{NRMz}, \mathrm{A} / \mathrm{m}$

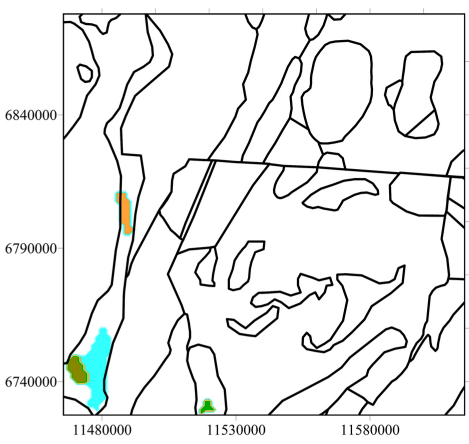

Layer from -9.5 to $-8.5 \mathrm{~km}$

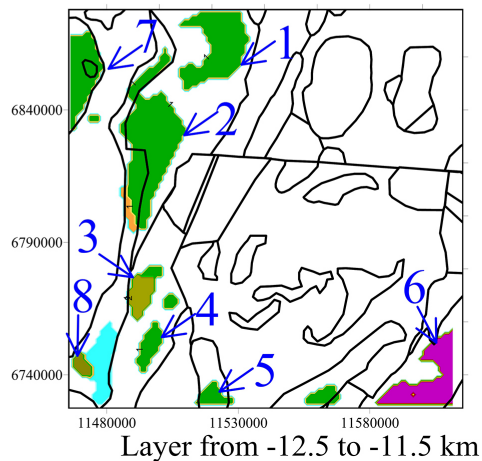

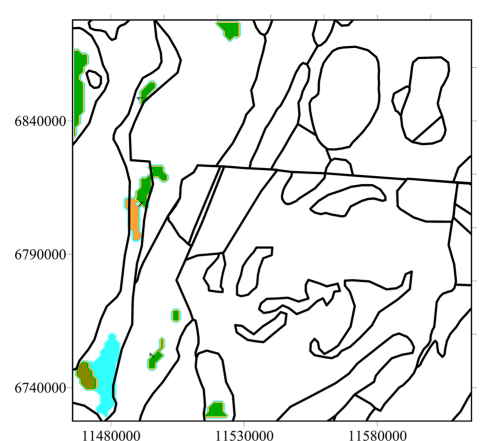

Layer from -10.5 to $-9.5 \mathrm{~km}$
$\mathrm{NRMz}, \mathrm{A} / \mathrm{m}$

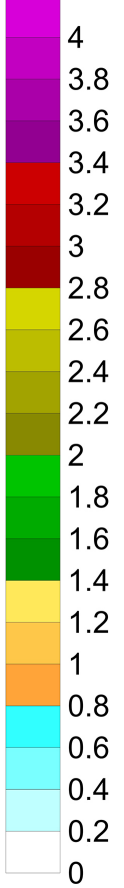

Figure 3. Natural remanent magnetization of the model. Contours of geological formations (Figure 1) are shown in black lines. On the bottom, right part (Layer from -12.5 to $11.5 \mathrm{~km}$ ) reverse remanent magnetization zones are marked by blue arrow with number. 
Magnetic susceptibility, SI units
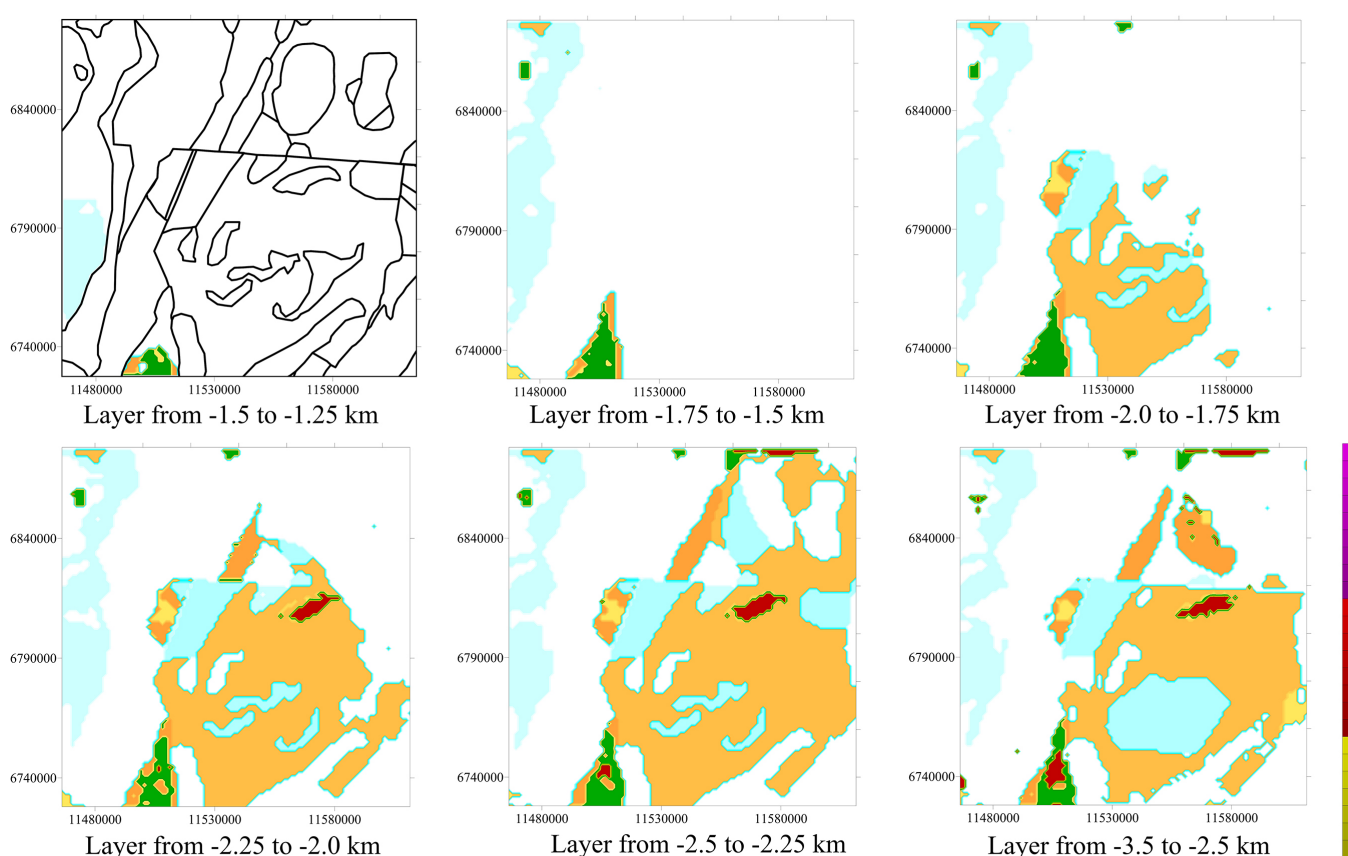

0.1

0.096

0.092

0.088

0.084

0.08

0.076

0.072

0.068

Layer from -2.5 to $-2.25 \mathrm{~km}$
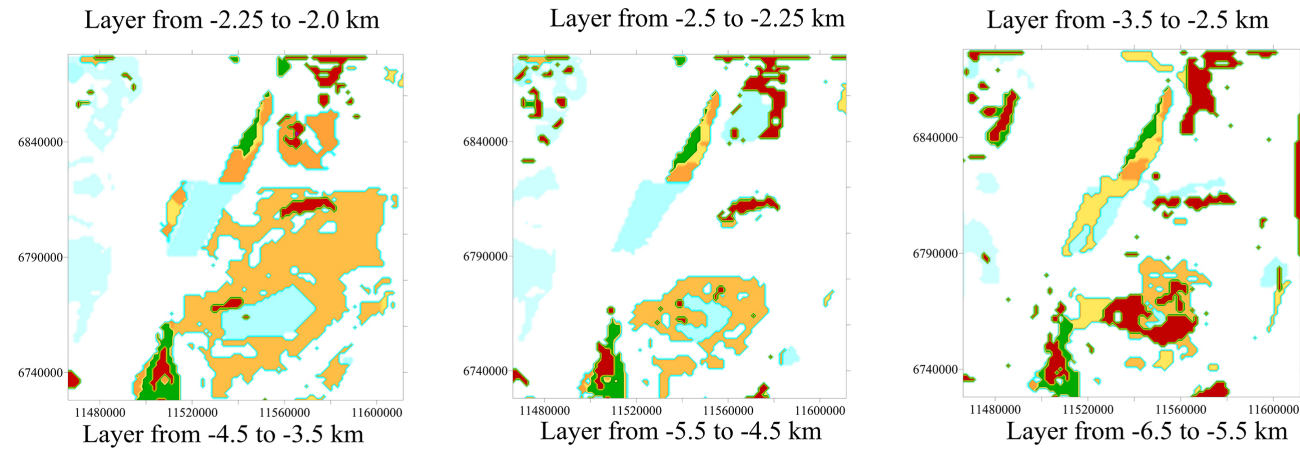

Layer from -3.5 to $-2.5 \mathrm{~km}$

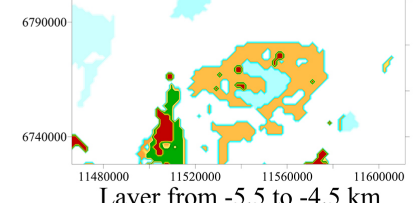

Layer from -5.5 to $-4.5 \mathrm{~km}$
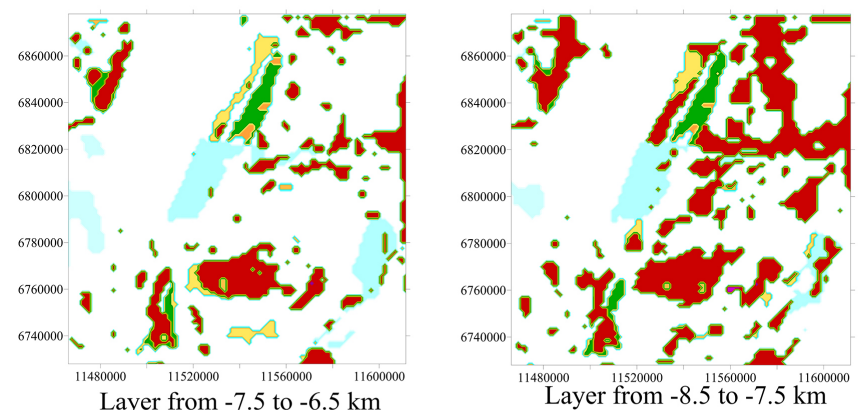

0.064

0.06

0.056

0.052

0.048

0.044
0.04
0.036

0.04
0.036
0.032

0.032

0.028

0.024
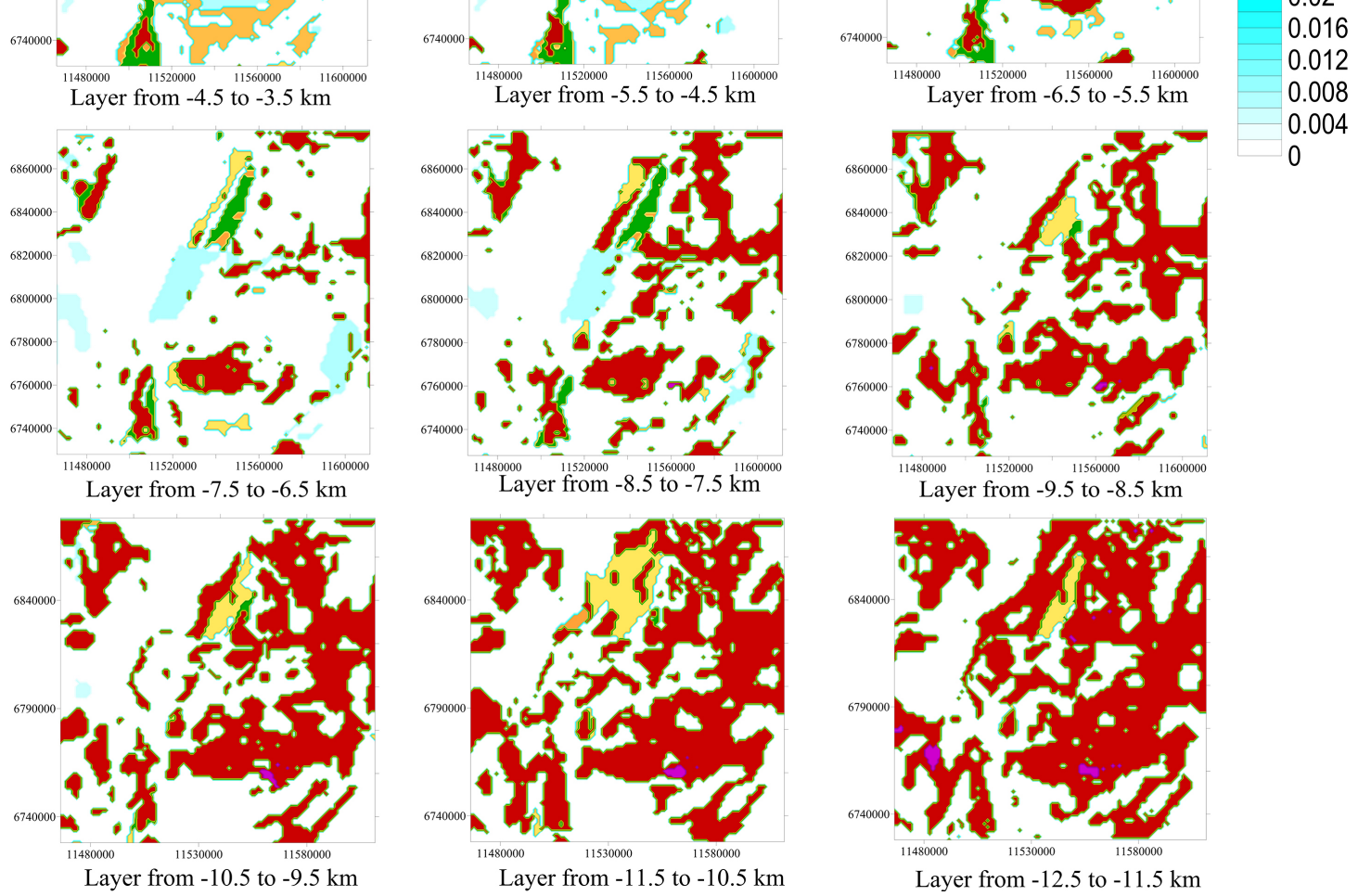

Figure 4. Layer by layer model of magnetic susceptibility of the study area in SI units. On the upper left part, contours of geological formations (Figure 1) are show in black lines. The scale is shown to the right. 
susceptibility of graben-rift basalts (shown in orange colors). At a depth range $1.75-2.5 \mathrm{~km}$ the liparites have worm-like structure that encountered by wells, below a depth of $2.5 \mathrm{~km}$ the liparites form lopolithlike body. Highly magnetic (having big magnetic susceptibility) areas (shown in red colors) are at the bottom of the model.

Let us consider vertical cross-sections of the magnetic susceptibility along profiles $(\mathrm{AB}, \mathrm{CD}, \mathrm{MN}, \mathrm{RS}$ and $\mathrm{OP})$ presented on Figure 1. The cross-sections are shown on Figure 5, vertical and horizontal scales coincide.

The profile MN from the southwest to the northeast (center of Figure 5) begins in a serpentinite zone (Figure 1) bounding the graben-rift from the west. Rocks model the periphery of serpentinites have magnetic susceptibility 0.02 0.04 SI units and reach a depth of $5.5 \mathrm{~km}$. There are practically nonmagnetic blocks underneath. Further, the profile intersect effusive rocks with tuffs, a

\section{A $B$}
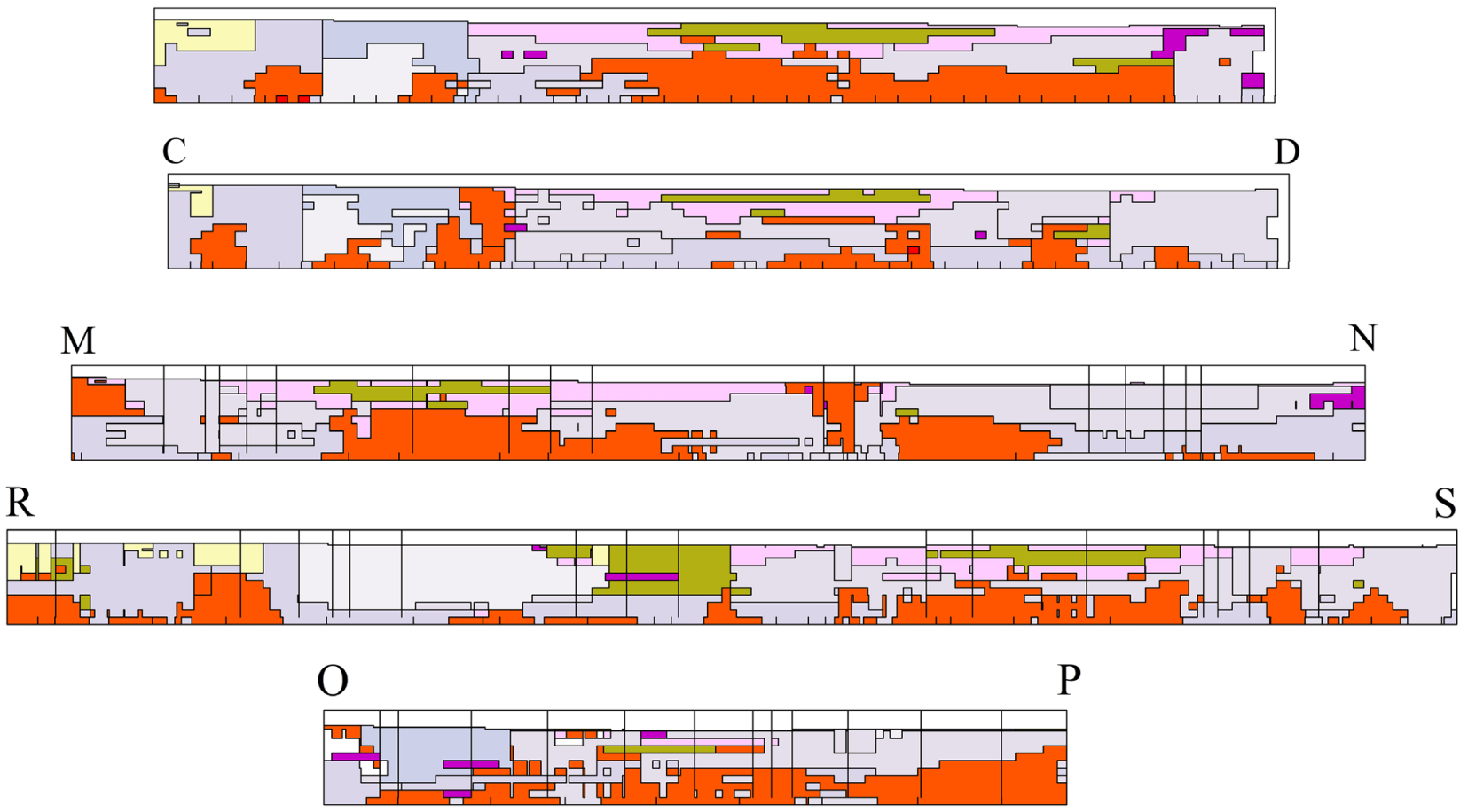

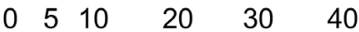

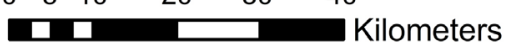

Magnetic susceptibility, SI units

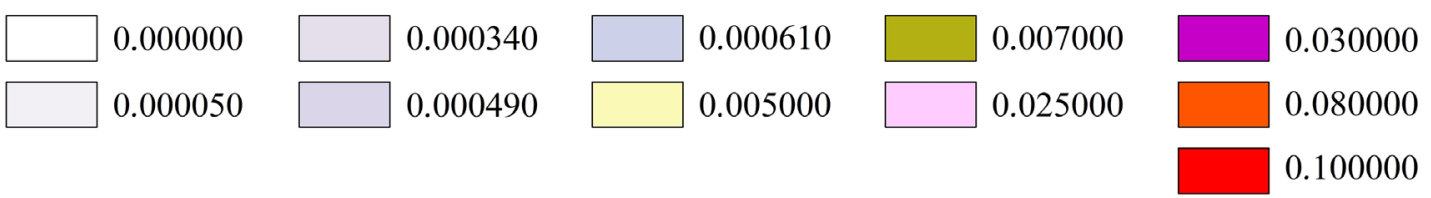

Figure 5. Cross-sections of the model along profiles (shown on Figure 1). Each cross-section begins with local zero coordinate. The scale is shown below. The vertical and horizontal scale are the same. 
negative anomaly under which partly taken into account by bodies with reversed magnetization (Figure 3, zone 5). Further on the cross-section clear seen basalts of the graben-rift with magnetic susceptibility 0.025 SI units and less magnetic liparites (0.007 SI units). At a mark of $40 \mathrm{~km}$, the profile intersect intense magnetic anomaly (Figure 2, the upper part) above weakly magnetized graben-rift basalts and liparites (Figure 1). The given anomaly can be explained by very magnetic rocks under the graben-rift. On the given cross-section this rocks come from a depth of $12.5 \mathrm{~km}$ to a depth of $5.5 \mathrm{~km}$. Further along the cross-section one can observe graben-rift bottom rising from the southwest to the northeast. Gabbro-dolerites massif (Figure 1) are marked by intense magnetic anomaly (about $600 \mathrm{nT}$ in the maximum) (Figure 2, bottom part), which can be seen at $100 \mathrm{~km}$ of the profile. An irregular body (Figure 4), which cross-section along the profile reaches a depth of $11.5 \mathrm{~km}$, models the anomaly. Further, there is a long low intensity anomaly (170 $\mathrm{nT}$ at the maximum). However, according to the geological map (Figure 1) here graben basalts are situated and to model the anomaly we entered magnetic body at a depth of 12.5 - $6.5 \mathrm{~km}$ (Figure 4 and Figure 5, profile MN). Further, effusive rocks with tuffs have near zero magnetic susceptibility.

The profile RS (Figure 5, cross-section RS), coming from the northwest to the southeast (Figure 1, Figure 2 upper part), gives us an insight into the transversal graben-rift structure. The graben-rift at this cross-section begins $100 \mathrm{~km}$ from the profile beginning (magnetic susceptibility 0.025 SI units). To the west of this point, magnetic bodies model Triassic liparites (Figure 1) with susceptibility 0.007 SI units. The cross-section comes through a circumference of serpentinites limiting graben-rift from the west. To the northwest Carboniferous terrigenous-schist formation has magnetic susceptibility near zero (0.00005 SI units) and give nothing to the anomaly. Surrounding magnetic rocks compensate only a half of intensity of the negative magnetic anomaly (about $-130 \mathrm{nT}$ in the minimum) and other half is given by deep seated (from 12.5 to $9.5 \mathrm{~km}$ depth) rocks (Figure 3, zone 2) with remanent magnetization opposite to the present main geomagnetic field. Above granitoids (from 20 to $40 \mathrm{~km}$ along profile), an intense magnetic anomaly (492 $\mathrm{nT}$ in the maximum) is modelled by rock underneath.

Coming back to magnetic structure of the graben-rift $(110 \mathrm{~km}$ along the profile and further) it should be noted its lopolith-like form manifested in magnetic properties and the bottom at a depth of about $5.5 \mathrm{~km}$.

Profiles $\mathrm{AB}$ and $\mathrm{CD}$ (Figure 5) come from the west to the east. At $40 \mathrm{~km}$ from the beginning, the profile $\mathrm{AB}$ intersects Late Devonian-Early Carboniferous effusives represented by practically nonmagnetic rocks. The profile $\mathrm{CD}$, situated $30 \mathrm{~km}$ to the south, intersects magnetic serpentinites, magnetic susceptibility of which changes from 0.06 to 0.1 SI units in the center and from 0.02 to $0.04 \mathrm{SI}$ units at the periphery. They give an anomaly by order of $1000 \mathrm{nT}$ in the maximum and bound the graben-rift at the west.

Nonmagnetic effusive rocks with tuffs adjoin to them. A negative anomaly 
$(-260 \mathrm{nT})$ above them are mainly due to magnetic serpentinites at the west, but requires reversely magnetized rock at a deps from 12.5 to $8.5 \mathrm{~km}$ (Figure 3 , zone 5) for full fitting.

The graben-rift is clearly seen in the plane (Figure 4) and on these cross-sections as rocks with magnetic susceptibility ranging from 0.02 to $0.04 \mathrm{SI}$ units and deepening in some places to $5 \mathrm{~km}$ depth. At the end of $\mathrm{AB}$ cross-section, further from $120 \mathrm{~km}$ and to the end, lowering of AMF (to -170 $\mathrm{nT}$ ) is observed. This part of the profiles comes through nonmagnetic Carboniferous terrigenous-schist formation. Negative AMF above it cannot be explained by induction of strongly magnetized rocks and require a deep-seated reversely magnetized body (Figure 3, zone 5). As can be seen from AB cross-section, under relatively weakly magnetized rocks of the graben-rift (basalts and liparites) there is a strongly magnetized block of rocks with magnetic susceptibility varying from 0.06 to 0.1 SI units at a depth from 8.5 to $12.5 \mathrm{~km}$. Magnetic susceptibility of graben-rift rocks (changing from 0.02 to 0.04 SI units) gives a wide positive AMF.

Profile OP demonstrates transversal cross-section of magnetic structure of the rock at the northeast (Figure 1), where the bottom of the graben-rift rises to the erosional truncation of the crystal basement. The profile begins from peripheral fragment of serpentinites, the most part of which are situated beyond the modeling area. This is reflected in magnetic susceptibility structure first $5 \mathrm{~km}$ along profile. Further, the profile intersects Late Devonian-Early Carboniferous effusives, basalts of the graben-rift (the thin stripe in the upper part of the cross-section with magnetic susceptibility $0.02-0.04$ SI units) and gabbro-dolerites (0.06 - $0.1 \mathrm{SI}$ units). Negative AMF around $70 \mathrm{~km}$ mark of the profile has engaged our attention because it is formed by strongly magnetized bodies (0.06-0.1 SI units) situated beyond its outline at a depth of $7.5 \mathrm{~km}$ at the northwest and rising up to a depth of $4.5 \mathrm{~km}$ at the southeast.

About magnetic susceptibility structure of granitoids and bordering sialic gneiss and schists laying to the west from the graben-rift on the basis of the RS and $\mathrm{AB}$ cross-sections (Figure 5) and layer by layer structure (Figure 4) it is possible to say that their magnetic susceptibility $(0.005-0.007$ SI units first 40 $\mathrm{km}$ along $\mathrm{RS}$ and about zero the first $20 \mathrm{~km}$ along $\mathrm{AB}$ ) is not big enough to generate the observed anomaly. To model the anomaly we enter highly magnetized rocks (0.06 - 0.1 SI units) underneath.

\section{Conclusions}

At modeling, we supposed that observed AMF does not have significant regional component above the modeling area.

The presented magnetic modeling confirms the results of gravimetric modeling that, in the first place, the studied structure is not a graben but a rift because continental light crust is absent in the structure (it pulled apart).

The modeling of magnetic susceptibility and natural remanent magnetization 
of the rocks in the limits of Danilov graben-rift of West Siberia reveals the presence of continuous magnetic rocks coming from a depth of $12.5 \mathrm{~km}$ with magnetic susceptibility of $0.06-0.1$ SI units, which can be interpreted as manifestation of a mantle diapir.

The modeling shows that some local zones of nonmagnetic (according to the geological map) rocks require entering at a depth of $7.5-12.5 \mathrm{~km}$ reversely magnetized bodies that can be explained if their formation took place in a period of geomagnetic field reversals or recursion. However, the hypotheses about obtaining reverse remanent magnetization in the course of metasomatosis and tectonic movement cannot be excluded.

The graben-rift structure traced by magnetic susceptibility points to that 1 ) the bottom of the graben-rift rises from the southwest to the northeast; 2) from the northwest to the southeast the graben-rift has lopolith-like structure with eastern fall of western borders marked by serpentinites and western fall of eastern borders.

In total, the modeling results allow confirming and refining geological assumptions on structure of Danilov graben-rift of West Siberia.

Potential field modeling limitation is well known ambiguity: infinitely many models can fit the observed field. The limitation may be overcome by taking into account geological considerations, drilling data and knowledge of genesis of the area. Further development of graben rock property modeling may lay in direction of creating a complex geophysical model incorporating density, magnetic and heat flow parameters.

\section{Funding}

The work was supported by Russian Science Foundation (Project 16-17-10201).

\section{References}

[1] Ivanov, K.S., Kucherov, V.G. and Fedorov, Yu.N. (2008) To the Question about Deep Origin of Oil. Proceedings ZapSibNIIGG Conference Condition, Tendencies and Problems Oil and Gas Potential of West Siberia Development, Tyumen, 160-173. (In Russian)

[2] Nezhdanov, A.A., Ponomarev, V.A., Turenkov, N.A. and Gorbunov, S.A. (2000) Geology and Oil and Gas Bearing of Achmovskaya Thickness of West Siberia. Publisher of Academy of Rock Sciences, Moscow. (In Russian)

[3] Miller, S.P. and Hey, R.N. (1986) Three-Dimensional Magnetic Modeling of a Propagating Rift, Galapagos 95³0'W. Journal of Geophysical Research, 91, 3395-3406. https://doi.org/10.1029/JB091iB03p03395

[4] Mariano, J. and Hinze, W. (1994) Gravity and Magnetic Models of the Midcontinent Rift in Eastern Lake Superior. Canadian Journal of Earth Sciences, 31, 661-674. https://doi.org/10.1139/e94-059

[5] Mugisha, E., Ebinger, C.J, Strecker, M. and Pope, D. (1997) Two-Stage Rifting in the Kenya Rift: Implications for Half-Graben Models. Tectonophysics, 278, 63-81. https://doi.org/10.1016/S0040-1951(97)00095-4

[6] MacLean, B.C. and Miles, W. (2002) Potential-Field Modeling of a Proterozoic 
Half-Graben near Blackwater Lake, Northwest Territories, Canada, and Its Implications for the Fort Simpson Magnetic Anomaly. Canadian Journal of Earth Sciences, 39, 169-187. https://doi.org/10.1139/e01-061

[7] Bhattacharji, S., Sharma, R. and Chatterjee, N. (2004) Two- and Three-Dimensional Gravity Modeling along Western Continental Margin and Intraplate Narmada-Tapti Rifts: Its Relevance to Deccan Flood Basalt Volcanism. Journal of Earth System Science, 113, 771-784. https://doi.org/10.1007/BF02704036

[8] Ebbing, J., Skilbrei, J.R. and Olesen, O. (2007) Insights into the Magmatic Architecture of the Oslo Graben by Petrophysically Constrained Analysis of the Gravity and Magnetic Field. Journal of Geophysical Research, 112, Article ID: B04404, 17 p.

[9] Bridges, D.L. (2011) A Geological and Geophysical Study of the Tendaho Graben in the Afar Depression, Ethiopia: Insights into Transitional Continental Rifting. Doctoral Dissertations, Missouri University of Science and Technology, Rolla, Missouri. http://scholarsmine.mst.edu/doctoral_dissertations/2020

[10] Alatorre-Zamora, M.A., Campos-Enríquez, J.O., Rosas-Elguera, J.G., Peña-García, L., Maciel-Flores, R. and Fregoso-Becerra, E. (2015) Chapala Half-Graben Structure Inferred. A Magnetometric Study. Geofísica Internacional, 54, 323-342. http://www.redalyc.org/articulo.oa?id=56842730003

[11] Lopes de Castro, D. (2011) Gravity and Magnetic Joint Modeling of the Potiguar Rift Basin (NE Brazil): Basement Control during Neocomian Extension and Deformation. Journal of South American Earth Sciences, 31, 186-198. https://doi.org/10.1016/j.jsames.2011.01.005

[12] Langenheim, V.E., Jachens, R.C., Muffler, L.J.P. and Clynne, M.A. (2016) Implications for the Structure of the Hat Creek Fault and Transfer of Right-Lateral Shear from the Walker Lane North of Lassen Peak, Northern California, from Gravity and Magnetic Data. Geosphere, 12, 790-808. https://doi.org/10.1130/GES01253.1

[13] Obi, D.A., Ilozobhie, A.J., Lebo, S.E. and Zoogbara, E. (2017) Modeling Magnetic Basement in Relationship to Hydrocarbon Habitats in the Central Niger Delta, Nigeria. Journal of Geography, Environment and Earth Science International, 10, 1-13. https://doi.org/10.9734/JGEESI/2017/31888

[14] Ivanov, K.S., Kormiltsev, V.V., Fedorov, Yu.N., et al. (2003) The Main Characters of Pre-Jurassic Basement Structure in Shaim Oil and Gas Bearing Region. The Way of Realization of Oil and Gas Potential of KhMAD. Proceedings of Viscientific-Pracical Conference, V.1. Khany-Mansiysk, 102-113. (In Russian)

[15] Rybakov, M.B., Goldshtein, V.I., Holl, D., Ben-Avraam, Z. and Lazar, M. (2011) New Ideas on Sources of Magnetic Anomalies in the East Mediterranean: A Key to Ophyolites and Gabbro Intrusion Localiation. Geologiyaigeofizika, 4, 487-511. (In Russian)

[16] Rostovtsev, N.N. (1964) Geology of the USSR. West-Siberian lowland. Geological Description, Nedra, Moscow, Vol. 44, 1-550. (In Russian)

[17] Ivanov, K.S., Puchkov, V.N., Fyodorov, Y.N., Erokhin, Y.V. and Pogromskaya, O.E. (2013) Tectonics of the Urals and Adjacent Part of the West-Siberian Platform Basement: Main Features of Geology and Development. Journal of Asian Earth Sciences, 72, 12-24. https://doi.org/10.1016/j.jseaes.2013.02.029

[18] Grachev, A.F. (1977) Rift Zones of Earth. Nedra, Leningrad. (In Russian)

[19] Kucheruk, E.V. and Ushakov, S.A. (1985) Plate Tectonics, Oil, and Gas Bearing (Geophysical Analysis). VINITI, Moscow. (In Russian)

[20] Milankovskiy, E.E. (1976) Rift Zones of Continents. Nedra, Moscow. (In Russian) 
[21] Elkin, E.A., Krasnnov, V.I., Bakharev, N.K., Belova, E.V., Dubatolov, V.N., Izokh, N.G., Klets, A.G., Kontorovich, A.E., Peregoedov, L.G., Sennikov, V.V., Timokhina, I.G. and Khromykh, V.G. (2001) Stratigraphy of Oil and Gas Bearing Basins of Siberia. Paleozoic of West Siberia. Publisher SO RAS, Subsidiary Geo, Novosibirsk. (In Russian)

[22] Bogush, O.I., Bochkarev, V.S. and Yuferev, O.V. (1975) Paleozoic of the South of West Siberia Plane. Novosibirsk, Nauka. (In Russian)

[23] Klets, A.G., Kontorovich, V.A., Ivanov, K.S., Kazanenkov, V.A., Saraev, S.V., Simonov, V.A. and Fomin, A.N. (2007) Geodynamical Model of Pre-Jurassic Basement-The Basis of Oil and Gas Bearing Zoning of Upper PreCambrian-Low Triassic Structural Stage of West Siberia Oil and Gas Bearing Province. Proceeding of Conference "The Way of Realization of Oil and Gas and Ore Potential of KhMAD", Khanty-Mansiysk, 13-17 November 2007, Vol. 1, 79-90.

[24] Fedorov, Yu.N., Ivanov, K.S., Koroteev, V.A. and Kormiltsev, V.V. (2004) Tectonic Structure of Transuralian Part of West Siberia Megabasin. Proceeding of Conference "The Way of Realization of Oil and Gas and Ore Potential of KhMAD", Khanty-Mansiysk, 2-5 December 2004, Vol. 1, 91-102. (In Russian)

[25] Kontorovich, V.A. (2007) Seismological Criteria of Oil and Gas Bearing of the Contact Zone of Paleozoic and Mesozoic Sediments of West Siberia. Geologiyai Geofizika, 48, 538-547. (In Russian)

[26] Ivanov, K.S. (2016) How Much Oil Does Russia Need to Produce? Uralian Geological Journal, 6, 3-14.

http://docs.wixstatic.com/ugd/15eb72_f0c0f560110b4165b2e7221570aef26e.pdf

[27] Rudkevich, M.Ya., Ozeranskaya, L.S., Chistyakova, N.F., et al. (1988) Oil and Gas Bearing Complexes of West Siberia Basin. Nedra, Moscow. (In Russian)

[28] Ivanov, K.S., Koroteev, V.A., Pecherkin, M.F., Fedorov, Yu.N. and Erokhin, Yu.V. (2009) History of Geological Development and Structure of the Basement of Western Part of West Siberia Oil and Gas Megabasin. GeologiyaiGeofizika, 50, 484-501. (In Russian)

[29] Fedorov, Yu.N., Ivanov, K.S., Zakharov, S.G., Kormiltsev, V.V., Erokhin, Yu.V., Pogromskaya, O.E., Knyazeva, I.V., Ronkin, Yu.L., Karetin, Yu.S., Surina, O.V., Purtova, S.I. and Glushko, N.K. (2003) Geological Structure and Stratigraphy of Triassic Sediments of the Northern Sosva Graben. Proceeding of Conference "The Way of Realization of Oil and Gas and Ore Potential of KhMAD", Khanty-Mansiysk, IzdatNaukaServis Vol. 1, 114-123.

[30] Kostrov, N.P., Kormiltsev, V.V. and Fedorov, Yu.N. (2005) System of 3D Interpretation of Gravitational and Magnetic Observations with the Aim of Geological Mapping of Pre-Jurassic West Siberia Complex. GornyeVedomosti, 1, 57-61. (In Russian)

[31] Kostrov, N.P. and Ivanov, K.S. (2017) Complex for Interpretation of the Potential Fields for Geology. Vestnik of IGG Komi Science Center of UrB RAS, 10, 3-8. (In Russian) https://doi.org/10.19110/2221-1381-2017-10-3-8

[32] Ananieva, E.M., Vinnichuk, N.N., Ivanov, K.S., et al. (2008) On Density of Rocks of East Urals and West Siberia Basement. UrB RAS, Yekaterinburg. (In Russian)

[33] Gusev, B.V., Metallova, V.V. and Fainberg, F.S. (1967) Magnetism of Rocks of Traps Formation of Western Part of Siberia Platform. Nedra, Leningrad. (In Russian)

[34] Chursin, A.V., Prutyan, A.M. and Fedorova, N.V. (2008) Digital Anomalous Magnetic Field Map of the Northern, Middle, Southern Urals and Adjacent Territoties 
of the East-European and West-Siberian Platforms. Litosfera, 6, 63-72. (In Russian)

[35] Kormiltsev, V.V. and Ratushnyak, A.N. (2000) Modeling of Geophysical Fields with the Help of Volume Vector Integral Equations. UrB RAS, Yekaterinburg.

[36] Eloranta, E.H. (1986) Potential Field of a Stationary Electric Current using Fredholm Integral Equations of the Second Kind. Geophysical Prospecting, 34, 856-872. https://doi.org/10.1111/j.1365-2478.1986.tb00498.x

[37] Kormiltsev, V.V. and Kostrov, N.P. (1999) Study of Algorithms Based on a Volume Vector Integral Equation for Magnetic Field Strength. VINITI, Moscow, 83-B99. (In Russian)

[38] Kormiltsev, V.V. and Ratushnyak, A.N. (1995) Vector Integral Equations for a Gradient of Potential Geophysical Fields. Rossiyskiygeofizicheskiyzhurnal, 5-6, 4-10. (In Russian)

[39] Kostrov, N.P. (2007) Calculation of Magnetic Anomaliescaused by 2D Bodies of Arbitrary Shape with Consideration of Demagnetization. Geophysical Prospecting, 55, 91-115. https://doi.org/10.1111/j.1365-2478.2006.00579.x

[40] Sharma, P.V. (1996) Rapid Computation of Magnetic Anomalies and Demagnetization Effects Caused by Bodies of Arbitrary Shape. Pure and Applied Geophysics, 64, 89-109.

[41] Atkinson, K.E. (1997) Thenumerical Solution of Integral Equation Soft the Second Kind. Cambridge University Press, Cambridge.

https://doi.org/10.1017/CBO9780511626340

[42] Blokh, Yu.I. (1987) Magnetic Field Calculation for Three-Dimensional Anisotropic Geological Objects with Corrections for Demagnetization. Izvestiya, Earth Physics, 23, 1003-1008.

[43] Ivanov, K.S., Kostrov, N.P. and Manushko, E.A. (2013) Deep Structure of the Danilovskii Graben in Western Siberia: A Geological Interpretation of the Density Models. Doklady Earth Sciences, 451, 870-874. https://doi.org/10.1134/S1028334X13080102

[44] Thébault, E., et al. (2015) International Geomagnetic Reference Field: The 12th Generation. Earth, Planets and Space, 67, 79.

https://earth-planets-space.springeropen.com/articles/10.1186/s40623-015-0228-9 https://doi.org/10.1186/s40623-015-0228-9 